\title{
Designing and Validating a Systematic Model of E-Advertising
}

\author{
Mohammad Reza Hamidizadeh (Corresponding author) \\ Associate Professor, Faculty of Management and Accounting, Shahid Beheshti University \\ Evin, Tehran 1983963113, Iran \\ E-mail: M-hamidizadeh@sbu.ac.ir \\ Nasser Yazdani \\ Faculty of Management and Accounting, Shahid Beheshti University \\ Evin, Tehran 1983963113, Iran \\ E-mail: yazdani20@gmail.com \\ Akbar Alem Tabriz \\ Associate Professor, Faculty of Management and Accounting, Shahid Beheshti University \\ Evin, Tehran 1983963113, Iran \\ E-mail: a-tabriz@sbu.ac.ir \\ Mohammad Mehdi Latifi \\ Faculty of Management and Accounting, Shahid Beheshti University \\ Evin, Tehran 1983963113, Iran \\ E-mail: mehdi.latifi@yahoo.com
}

Received: November 28, $2011 \quad$ Accepted: January 30, $2012 \quad$ Published: April 1, 2012

doi:10.5539/ijms.v4n2p130 URL: http://dx.doi.org/10.5539/ijms.v4n2p130

\begin{abstract}
The paper's aim is that how the electronic system is able to transmit the message and is considered as an advertising tool, influencing factors on consumer's behavioral response should be identified in order to use this media desirably, effectively, and utilize the e-advertising advantages to satisfy consumers' needs. This is a research an applied research and a descriptive one with field studies. There are some casual relationships among the research variables. A questionnaire is used to collect data. This study aims to designing, validating, and evaluating a model which explains the influence of e-advertising on consumer behavior as well as providing strengths and weaknesses of the model and suggesting solutions to enhance strengths and converting weaknesses to strengths. In this paper, capabilities of internet advertising are examined in a form of 14 content and communicate motives via a leading process (cognition, affection, and attitude) on consumer's behavioral response (image and mentality, intention and desire, testing, purchasing and consuming) as "an e-advertising model" in Tehran Refah Chain Stores. Results show a suitability of the fitted structural model. The above mentioned company, however, should improve its website's capability in content and communicate motives. In this way, internet advertisings of Refah Chain Store's are able to have a desirable effectiveness in order to lead the consumer behavior.
\end{abstract}

Keywords: E-advertising model, E-advertising motives, Content motives, Communicating motives, Effectiveness process, Consumer's behavioral response

\section{Introduction}

One of the most important developments in recent years is the growth of information and communication technology (ICT) and subsequently the growth and development of electronic tools of communication. In these 
years, we have faced the widespread dominance of sending-receiving tools electronically. Several electronic systems including internet have changed the communication world and given particular opportunities to communication ways. Internet based advertising is an important mechanism that companies utilize in order to communicate with their customers. Internet advertising has become an important channel of marketing for companies. Utilizing the Internet advertising, companies can stabilize their brand's position, transmit information, and promote their business transactions which are influencing and important processes. Companies need advertisements in order to implement both their sales and profiting goals. As companies spend a lot on these issues, they can utilize e-advertising suitably in order to reduce expenses. In order to plan precisely and effectively, however, the process of consumer's behavioral response to e-advertising should be recognized with regard to its capabilities. Therefore, investigating and identifying the dimensions of this new media is an important issue which should be considered precisely. In addition, the behavior and attitude of consumers to different aspects of internet advertisings such as entertaining, informativeness, irritation, etc should be studied in order to utilize its capabilities efficiently. In this research, with regard to the influencing factors in the model, it is tried to study and recognize the e-advertising factors as well as its influencing process on consumer behavior. The main purpose of this study is to design and validate a model which explains the influence of e-advertising on consumer behavior.

\section{Theoretical Background}

\subsection{E-advertising}

E-advertising is a form of promotion that uses the internet to deliver marketing messages to attract customers. E-advertising types which are studied in this research include contextual ads on search engine results pages, banner ads, blogs, rich media ads, social network advertising, interstitial ads, pop-ups, online classified advertising, advertising networks and e-mail marketing, including e-mail spam. According to Sepstrup (1991), an ideal advertisement is the one which have the highest accessibility to potential customers, high capability of giving feedbacks, and low cost. Which media is the one that delivers an ideal advertisement to the advertiser? An advertisement is an entity of concepts which can be used to supply the market with products on the basis of making a relationship with customers. This entity has actually two areas; the first area is marketing; its goal is to create, communicate, and deliver value to customers. The second area is communication which is a process of creating a unique thought between a sender and a receiver. From an economic view, advertisements have two main functions. The first one is persuasion and the second one is an information basis. A successful advertisement is the one which has a high economic-persuasion function. The informativeness function is very important. According to Little Child, in our world in which uncertainty dominates and people in communities have low levels of knowledge, the informativeness role of advertisements is vital. As customers usually have little information, data offering companies can complete people's information and create some kind of loyalty in them. Increasing customer loyalty secures future revenues and minimizes the possibility of defection if quality decreases. In the early outburst of internet advertisings, advertisements were mostly like colorful rectangular shapes which were called Banners. These kinds of advertisements spread quickly. The website that demonstrated the first advertising banner was www.hotwired.com in 1994 which exposed banners of some companies such as Zima, Volvo, and AT\&T to users. With improvements in internet communication infrastructure and more accessibility of users to higher bandwidths, advertisers used more graphics in advertisements. The purpose of primary advertisements was to persuade potential customers to see the advertiser's website. But new advertisements are transmitters of a comprehensive message themselves. Their texts change constantly to transmit a better message to users. This can make specific users enter the website rather than every user. As illustrated in Figure 1, when advertising in internet environment is considered, recognizing the situation and its influencing factors will become important.

\subsection{Elementary Model}

Luis, the first one who wrote an "Advertisement Book" in 1898, proposed his famous four-word method which includes attention, interest, desire, and action in order to make the advertisements effective. A study was conducted by Lavidge and Steiner in 1961 which resulted in introduction of "Hierarchy of effects" or "Cognitive, Affective \& Behavior" (CAB) which is illustrated in Figure 2. In this hierarchy which was done, attention leads to interest, interest leads to belief, belief leads to desire, and eventually desire leads to action. These elements were then classified in a larger category of cognition, affection, and attempt (which was entitled "behavior" thereafter). Therefore, the consumer behavior is considered as an important index for measuring effectiveness.

Attitudes are internal feelings and behaviors are their external symbols. Several factors are involved in forming attitudes. Humans are born with specific characteristics which are involved in forming their attitudes. But 
influencing factors on humans' life to form their attitudes are much more important than those characteristics and their effects on humans are permanent. It is considered that attitudes have three main components:

1). Cognitive or mental- or an individual's beliefs about a phenomenon such as speed or its durability.

2). Affective or emotional- or an individual's feelings about a phenomenon such as being good or being bad.

3). Behavioral- or an individual's readiness in behavioral response to a phenomenon. It is important to know consumers' attitudes about advertisements, their perception, their evaluation, and eventually their behavior about internet advertisings. Wang and Zhang (2006), in their important field research, believe that there are four influencing factors on customer's attitudes and values about advertisements: Entertainment; Irritation; In formativeness; credibility.

They believe that being interactive and demographic are other influencing factors on customer's perception and behavior. Ducoffe (1996) suggested a framework to predict consumer's attitudes and values about advertisements. Entertaining, irritation, and informativeness are considered as influencing factors on evaluating values and then consumer's attitudes about advertisements. After that, he applied a model in his network environment and confirmed his previous finding that attitudes toward network advertisements depend on the resulting value from them. In addition, the resulting value from advertisements depends on their entertaining levels, their irritation levels, and their informativeness levels. A study was conducted by Rodgers in 1990 in which 100 motives of using the internet was identified and classified in four categories which include searching, purchasing, recreation, and communicating. Barker \& Groenne (1996), in studying the applied value strategies in internet, found that the value in internet advertisings is created in three ways: informativeness; Entertaining; Purchase facilitation. They argue that the level of consumer's involvement should be also considered. In another study, Ducoffe (1996) found that the resulting value from the entertaining factor in internet advertisings depends on its ability to saturate emotional needs. He believes that entertaining and informativeness factors arise from advertisements' content. Korgaonkar \& Wolin conducted a study in 1999, identified 45 motives and interests of using the internet, and classified them in 7 groups: Social escape, independence and safety of exchange, interactivity control, Socializing, non-exchange independence, and economic motivation. These researchers expressed that people use the internet due to 3 main purposes: getting information, recreation, and spending their leisure time. Another study was conducted by Papacharissi \& Rubin in 2000 in which motivations for using the internet was identified. They categorized the primary motives in 5 groups: interpersonal desirability, recreation, information search, convenience, and entertainment. A study conducted by Korgaonkar \& Wolin in 2003 showed that males perceive internet advertisings as being enjoyable, useful, and instructive while females perceive them as being aggressive, painful, seductive, and useful. Anne Schlosser, Sharon Sharitt \& Alaina Kanfer (1999) addressed the comparison between traditional advertising and internet advertising. They also explained the characteristics of audiences thought about internet advertising as well as how they can be utilized better by improving their design. They surveyed a case study of 400 samples and concluded that $1 / 3$ of the samples liked internet advertisings, $1 / 3$ didn't like them, and $1 / 3$ were neutral. Regression analysis shows that enjoying internet advertisings, their informative role, and using them for a behavioral decision making (purchasing) is related to people's attitudes about internet advertisings (IA). Brackett \& Carr (2001) confirmed and extended Ducoffe's model in that they added two more factors of credibility and demographic (categorizing consumers) to the model. Effectiveness factor of credibility is directly related to both a resulting value and a resulting attitude from advertisements. Demographic variables such as education and gender (male and female) showed that they just influence the attitude toward advertisements. An important difference between traditional advertising and internet advertising is in that the interaction level of a consumer can be examined by an advertisement differently. Research findings show that interaction is a factor which can influence the consumer's perception about his/her value and attitude toward an advertisement. Rath Rettie, Helen Robinson, \& Blaise jenner (2003) studied internet advertising effectiveness. Unlike the findings of Ducoffe (1996) and Schlosser (1999), their findings showed that internet advertising hurt most of the consumers, may have a negative effect on advertiser's brand, and if users use the internet more, their resentment from internet advertising will increase. Ng ka Po (2006) claims that using the internet and paying attention to its applications have been increased in recent years and as a result its interaction and dynamism have become generalized and accepted although its effectiveness is decreasing due to some reasons. When the experience of users from using internet increases, its effectiveness decreases; because internet users think that advertising in this environment is irritating and try to block them. $\mathrm{Ng}$ ka Po (2006) studied the influencing factors on consumer's attitudes toward web advertisements which increase its effectiveness. He believes that in studying internet advertising, it is not possible to use the influencing factors on advertisements' effectiveness which were used to study traditional media. Therefore, his research addresses the influences of content factors, emotional feeling factors, and brand name factors on the effectiveness of internet 
advertising. Actually the principal and interactive influences of these factors on attitudes toward both internet advertising and purchasing intentions are studied. Results show that only contents and brand names influence the attitude toward advertising. The influence of advertising content is related to the content of the host website which shows the advertisement and this causes a desirable attitude toward advertising. A famous brand name causes a more desirable attitude toward internet advertising. Results also show that a positive attitude toward internet advertising leads to a positive attitude toward purchasing intentions. Zhang Hong Xia, Li Jia Hean Tatken (2004) believe that advertising value is an intellectual evaluation of the consumer from the value or the relative use of advertisements. They implemented a research in 2004 on how Chinese evaluate advertising value. Results are as:

1). Informativeness, entertaining, and collective motivation have a positive relation with the resulting value from advertising. Similarly, advertisements that encourage collective motivation have a positive relation with their resulting value.

2). Persuasive tactics of advertising have a negative relation with the resulting value from advertisements. In other words, it causes a negative effect on the resulting value from the advertisement which Chinese believe advertisers have used to influence their behavior.

3). The resulting value from advertisements has a positive effect on purchase intention. It means Chinese who are positively influenced by the resulting value of advertisements might have a stronger purchase intention.

Fontini Patsioura, Maro Vlachopoulou \& Vicky Manthou (2009) performed a research on a new model of advertising effectiveness for advertising websites of companies. The purpose of their research was to give a conceptual framework of effectiveness to evaluate the performance of advertising websites of companies in order to perform multiple advertisements, promotions activities, and communication based marketing. Data were collected by questionnaires which had been completed by 160 students and graduates. Findings showed that meaningful dimensions of people's behavior are based on their activities, their movements, their desires, and their intentions. Results also showed that qualitative factors of communication based marketing have considerable effects on indexes of advertising effectiveness. Factors of e-advertising which were studied are as the following:

1- Ads Content, 2- communications, 3- feedback, 4- servicing the consumer/ customer, 5- interaction, 6Aesthetics affect. Ying Wang \& Shaojing Sun (2010) performed a new research in order to investigate the role of beliefs and attitudes in online marketing comparatively, in United States and Romania. The aim of this research was to study online (electronic) advertising in different cultures such as the ones in Romania and United States. The main purpose was to examine the relations between beliefs about online advertising, attitude toward online advertising (ATOA), and consumer's response to online advertising. The research was done via 577 internet users in Romania and United States, and the relationships between variables were examined using a structural equations model.The research findings show that belief factors (such as information search, entertaining, economizing, credibility, and corruption value) were meaningful statistical predictors for ATOA, and ATOA itself is an important predictor of a consumer's response to online (electronic) advertising. Comparing to Americans, Romanians had more positive tendency to ATOA and probably click the advertisements more, while Americans had more tendency to online purchasing.

\subsection{Previous Research}

A consumer behavior will be formed after his/ her attitudes and beliefs are formed. If his/ her attitudes are more positive, it will be more probable that his/ her behavior occurs in future. One of the ways of creating a positive attitude in consumers is utilizing the capabilities of internet advertising. This can shape positive cognitions, positive feelings, and positive behaviors. Therefore, identifying the e-advertising capabilities and its influencing process in order to recognize and lead the consumer behavior is very important for advertisers. With regard to above mentioned procedures, factors and motives of each research are utilized in order to create a new model which is illustrated in figure-3. This model consists of the influencing factors on e-advertising and explains the e-advertising process.

1). Considering that a systematic approach is used in this model, the inputs are effective motives in a framework of content motives and communicate motives as figure 4 .

2). According to the leading process, the above mentioned motives lead to both intellectual- cognitive response and emotional- affective response. Consumer's beliefs, emotions, and attitudes are formed in this process as figure 5 .

3). According to content motives and communicate motives of e-advertising as well as the leading process; 
consumer behavior response explains effectiveness measurement of the model. Consumer behavior responses are explained in figure 6.

\section{Hypotheses Development}

With regard to the conceptual framework of research and the relationships among the identified variables (independent variables, dependent variables, and mediator variables), the following hypotheses are formulated:

Hypothesis 1: Content motives have a significance positive influence on consumer's cognitive response.

Hypothesis 2: Content motives have a significance positive influence consumer's affective response.

Hypothesis 3: Content motives have a significance positive influence consumer's attitudes.

Hypothesis 4: Content motives have a significance negative influence consumer behavior.

Hypothesis 5: Communicate motives have a significance positive influence consumer's cognitive response.

Hypothesis 6: Communicate motives have a significance positive influence consumer's affective response.

Hypothesis 7: Communicate motives have a significance positive influence consumer's attitudes.

Hypothesis 8: Communicate motives have a significance positive influence consumer behavior.

Hypothesis 9: Cognitive response has a significance negative influences consumer behavior.

Hypothesis 10: Affective response has a significance positive influences consumer behavior.

Hypothesis 11: Attitudes have a significance positive influence consumer behavior.

Hypothesis 12: Consumer's behavior response has a significance positive influence the validity of e-advertising model.

\section{Research Methodology}

The research is an applied one based on its aims and in terms of nature data gathering, it is a descriptive one. With regard to data collection methods, this research is considered in field studies. There is also a casual relationship between the research variables. A questionnaire is used to collect data. Independent variables are e-advertising motives (content and communicate), dependent variable is a consumer behavior response, and mediator variable is a consumer leading process (cognitive response, affective response, and attitude). The existing relationships between these variables are studied in a correlation or a covariance matrix, and using the exploratory factor analysis and structural equations model specially the path analysis is necessary. Therefore, 91 five-choice questions were designed based on the research variables. Table 1 illustrates the questions and the research variables. With regard to Cronbach's Alpha coefficient and exploratory factor analysis, 91 questions were developed for the primary questionnaire. After applying validity and reliability tests, 12 questions were omitted and as a result the eventual questionnaire had 79 questions. In surveying different companies and advertising websites, it was concluded that as Refah Chain Stores in Tehran are leading and pioneer stores in offering advertising sites and introducing different groups of products, they can be a suitable statistical population for this research. The sample size is 267 which is base on a conservative view by its proportion.

Statistical population is customers of Refah Chain Stores in Tehran. Using Cochran's formula, the sample size is 276. The sampling method is based on the observable characteristics of population according to maximum estimate discretionary of the observed number of customers in Refah Chain Stores and it took two months to collect all data.

Dependent variables and independent variables are measured according to path analysis. Path analysis of the structural model is a technique that shows the relationship between the research variables (dependant variables, independent variables, and mediator variables) simultaneously. The purpose of path analysis is to identify causality between variables of the conceptual model of the research. It should be noted that the common method bias is normal $(\alpha=0.05)$.

The construct, the concept, and variables have direct relationships with each other in a way that the concept can be reached from the construct and similarly variables can be reached from the concept. Variables of this research are selected according to indicator that previous researchers had used in their studies. Using the Likert 5-range scale, Questions of the questionnaire are designed according to the relationship between variables and the mentioned indicators. Each variable is measured according to the responses of the population to each question.

\section{Finding Analysis}

First, statistical test of one- sample average is used to study the variables' status and achieve their functional 
quality in Refah Chain Stores website. Using the Likert 5-range scale, the average scores of 3 were considered moderate, less than 3 were considered below moderate, and more than 3 were considered above moderate. Results are explained in table 2.

Table 2 shows the collected data about analysis of each independent motives, mediator motives, and dependent motives. Each of these motives explains that they should be redesigned and reapplied better. Considering the research hypotheses that put 14-fold motives in two groups of content motives and communicate motives, exploratory factor analysis is used to decrease data and identify the structure of latent variables. After implementing exploratory factor analysis in 2 steps and with regard to KMO test, Bartlett test, and research background, it is logical that these motives ( 7 motives) be called "Content Motives" in exploratory factor analysis. Similar results for other 7 motives have been achieved in exploratory factor analysis and show that 7 motives are summarized in one group. Therefore, according to the research literature, it is logical to call them "communicate motives". Therefore, content motives and communicate motives were identified as two independent variables in research hypotheses.

In addition, KMO and Bartlett tests about exploratory factor analysis for mediator motives and dependent motives prove that these variables are significant. Therefore, according to exploratory factor analysis, 6 independent variables, mediator variables, and dependent variables are significant as: 1. Independent variables: a) content motives. According to confirmatory factor analysis of the first step in questions of the questionnaire, dimensions of 7 motives about quality and desirability were found: Informativeness; Entertaining; Irritation; Credibility; Demographic; Searching; Updating/ Customized. Then, according to confirmatory factor analysis in second step, "content motive" is reached from 7 factors (motives). From dimensions of content motives, a demographic motive has the most effect with factor loading of 0.76 . It means that this motive explains approximately $58 \%$ of variances of content motives. In addition, the model's fit indexes show the suitability of measurement model.

RMSEA is 0.064 and as it is less than 0.08 , the model's error square average is suitable. Moreover, Chi-square value to degree of freedom is less than 3 . The values of AGFI, GFI, and NFI are $0.91,0.90$, and 0.96 respectively. Therefore, the first independent variables (content motives) are suitable due to the model's fit indexes. 7 motives of quality and desirability were reached due to confirmatory factor analysis in the first step including Interactivity, Accessibility, Global, Purchase facilitation, Personalize, Economizing; Measurement and feedback. Then, according to confirmatory factor analysis in the second step, 7 factors (motives) of "communicate motives" were reached. Between dimensions of communicate motives, a "measurement and feedback motive" has the most effect with factor loading of 0.71 . In other words, it explains approximately $51 \%$ of communicate motives variance. The model's fit indexes show the suitability of the model's measurement.

RMSEA is 0.06 and as it is less than 0.08 , the model's error square average is suitable. In addition, Chi-square value to degree of freedom is less than 3 . The values of AGFI, GFI, and NFI are $0.90,0.92$, and 0.95 respectively. Therefore, according to the model's fit indexes, the second independent variable (communicate motives) is suitable. According to confirmatory factor analysis of mediator and dependent variables in a standard estimate, the indexes are comparatively suitable. Chi-square value to degree of freedom is less than 3 , RMSEA value is 0.069 which is less than the limit (0.08), and the values of AGFI, GFI, and NFI are 0.89, 0.92, and 0.99, respectively. These values show the model's suitable fit of measurement.

Actually, cognitive response, affective response, and attitudes are mediator variables and influence the relationship between dependent variables (consumer behavior response) and independent variables (content motives and communicate motives).

\section{Structure Equation Model (SEM) Results}

In this research, a structure equation model specially the path analysis is used to confirm or reject hypotheses. Path analysis (structurre model) is a technique which shows the relationships between research variables (dependent variables, independent variables, and mediator variables) simultaneously. The purpose of path analysis is to identify the causality (effect) between the variables in the research conceptual model.

The reflective model that is illustrated in figure 7 and figure 8, shows the relationships among content motives, communicate motives, cognitive responses, affective responses, attitudes, and behavioral responses. The idioms of these two figures have the descriptions which presented in appendix. This structural model with a standard estimate shows:

- Content motives have a positive (0.28) and a significant effect (4.54) on the cognitive response.

- Content motives have a positive (0.24) and a significant effect (4.17) on the affective response. 
- Content motives don't have a positive (0.09) or a significant effect (1.77) on the behavioral response.

- Content motives have a positive (0.23) and a significant effect (3.66) on attitudes.

- Communicate motives have a positive (0.45) and a significant effect (6.41) on the cognitive response.

- Communicate motives have a positive (0.52) and a significant effect (8.51) on the affective response.

- Communicate motives have a positive (0.56) and a significant effect (8.58) on attitudes.

- Communicate motives have a positive (0.72) and a significant effect (9.81) on the behavioral response.

- Cognitive response doesn't have a positive (0.09) or a significant effect (1.82) on the behavioral response.

- Affective response has a positive (0.80) and a significant effect (10.88) on the behavioral response.

- Attitudes have a positive (0.25) and a significant effect (4.49) on the behavioral response.

In testing research hypotheses using structural equations model, the software's output shows the suitability of fit structural model for testing the hypotheses. The ratio of $\chi^{2}$ to $\mathrm{df}$ is less than 3 . So $\chi^{2}$ has a suitable value. RMSEA $=0.044$; this also shows the suitability of a structural model fit. In other words, the observed data are consistent with the conceptual model of the research. The values of GFI, AGFI, and NFI are 0.92, 0.93, and 0.99 respectively. These values show the model's high fit and confirms the last hypothesis. From 12 research hypotheses, 10 hypotheses are confirmed and 2 ones are rejected.

\section{Discussion, Conclusion, and Implications}

1). According to table 2, it is obvious that respondents have selected the entertaining motive, searching motive, availability motive, and economizing motive more than other motives while 8 other motives of content and community (the ones as consumer persuasive characteristics in websites of Refah chain stores) have a weak status. Two other motives of "global" and "purchase facilitation" show a moderate status. These motives' status show that Iranian websites which do the advertisements electronically, including Refah Chain Stores websites, were not able to create and use suitable characteristics, suitable capabilities, and suitable advertising motives. Therefore, according to responses of customers who use Tehran Refah Chain Stores websites, several modifications should be applied to these websites in order to be in a better condition and an acceptable status.

2). According to the sample adequacy size (KMO) and significance of Bartlett's test of sphericity in exploratory factor analysis, all of 7 content motives and 7 communicate motives are summarized in one variable. Base on the research literature and above mentioned significant tests, it is logical to name each category of the septet motives as "content motives" and "communicate motives". This achievement, the research findings, and a research model introduce two categories of influencing motives in an electronic (internet) environment.

3). The sample adequacy size (KMO) and significance of Bartlett's test of sphericity in explanatory factor analysis of mediator variables (cognitive response, affective response, and attitudes) and a dependent variable (behavioral response) indicate that applying this process during e-advertising effectiveness can suitably determine a consumer's leading path to reach the behavioral response. Usually, expecting a real time and short-term influence of advertising on customers is impracticable and it should be implemented during time and via a good process. Therefore, this process usage in the model and its significance as mediator variables can be utilized suitably in different products and services with regard to their involvement level.

4). According to confirmatory factor analysis about independent variables (content motives and communicate motives), it is obvious that each of 7 motives in each content or communicate categories has a desirable factor loading in explaining the corresponding variable variance. Among content motives, the demographic motive has a factor loading of 0.76 which explains approximately $58 \%$ of content motives variance. Among communicate motives, the measurement and feedback motive has the most influence on the concept of communicate motives. The factor loading of a measurement and feedback motive on communicate motives is 0.71 which explains approximately $51 \%$ of communicate motives variance. With regard to the indexes of the model's fit which indicate suitability of a measurement model, it should be noted that if all of the motives be used suitably as the mentioned motives, they will have desirable impacts on effectiveness process of e-advertising.

5). Hypotheses were studied and tested, and the relationships between variables have been explained before. Considering that content motives don't have any influence on a behavioral response, it can be stated that after gaining the required information and other content data about internet advertising, a consumer will not reach the behavior step; rather he/ she should go through a leading process (cognition, affection, attitude) in order to be able to reach a behavioral response. In other words, real time advertising doesn't have any effect on products which require more involvement and thinking levels. Therefore, its influencing steps should be passed over 
according to the model.

6). According to studying and testing hypotheses, a cognitive response doesn't have any influence on a consumer behavior (behavioral response). This confirms that a cognition (gaining information) doesn't lead to purchase behavior necessarily. Therefore, in most products and services, a consumer should go through both the affection and the attitude level in order to reach the action level.

The relationships between independent variables, mediator variables, and dependent variables confirm totality of the model. It means that content and communicate motives will reach the behavioral response after going through the leading process (cognition, affection, and attitude). Companies including Refah Chain Stores should utilize all of the introduced motives in the model, put them in content and communicate frameworks, and use the leading process in order to influence consumers about their products and services via an advertising website. Utilizing this model which has a high and a suitable fit can help companies in e-advertising. This can make them improve their websites in content and communicate points of view.

As it was observed, the content and communicate motives in the examined population didn't have a desirable quality. According to hypotheses testing results and the model's suitable fitness, it can be concluded that consumers' final response can be influenced by suitable usage of content and communicate motives. If the companies pay attention to these motives and their dimensions in designing their e-advertisings, they can achieve effective results. This new media is an alternative for traditional media such as TV, radio, newspapers, etc. Actually, using effective e-advertisings, companies will gain more benefits from the target market at less cost.

With regard to the research findings, results, and limitations which were faced the development of e-advertisings among companies and institutions, it is recommended to extend this research in the following dimension:

1). The times that users spend in internet as well as their use of internet are important factors which should be considered in future research.

2). Products and services types are important factors for designing a good advertisement. This means that depending on the kinds of products which are going to be introduced and advertised to customers in advertising websites, special motives should be used. Therefore, implementing a research with regard to categorizing products and services can result in new and useful findings.

3). Testing the suggested e-advertising model via websites of fully private stores and companies as new statistical populations can result in new and desirable findings.

4). It is suggested to implement a research about e-advertising in fully virtual stores or companies.

5). According to the results about education of respondents, it is suggested to implement a research in a statistical population in which respondents have high educations and use internet and advertising websites more, such as academics and graduates.

6). Considering that there are different advertisings such as banners, pop ups, etc in internet, it is suggested to implement a research about the effectiveness of these different advertisings and forms of e-advertisings.

7). Implementing a research about characteristics of an effective advertisement from customers' viewpoints can be useful.

8). Like most of other phenomena in humanities and management which have different reasons, in other words each effect has different causes as independent and mediator variables, studying other influencing factors (independent variables) on e-advertising effectiveness such as education, income, products and services types, brands, etc can be useful.

9). Comparing the effectiveness of e-advertising and traditional advertising in a special actuarial population can provide good results about the consumers' viewpoints.

10). Implementing a research about e-advertising, its influence with regard to the product life cycle, and the kind of advertising which would be more suitable and effective in each stages of a product life cycle can give useful results to companies.

\section{References}

Barker \& Gronne. (1996). Advertising on the World Wide Web. Thesis, Copenhagen Biz. School, DK.

Barry, T. E., \& Howard, D. J. (1990). A review and Critique of the Hierarchy of Effects in Advertising. International Journal of Advertising, 9, 121-135.

Belch, George E., \& Belch, Michael A. (2003). Advertising and Promotion: An Integrated Marketing 
Communication Perspective. New Delhi: Tata Mc Graw -Hill Publishing Co.

Belk, R. W. (1975). Situational Variables and Consumer Behavior. New York: Prentice-Hall Pub. Co.

Bendixen, Mike T. (1993). Advertising Effects and Effectiveness. European Journal of Marketing, MCB University, 27 (10).

Bennett, Anthony. (1997). The Five V's - A Buyer Perspective. Marketing Intelligence and Planning, 15 (3), 151-156. http://dx.doi.org/10.1108/02634509710165957

Bettman, J.R., Johnson, E.J., \& Payne, J.W. (1991). Consumer Decision Making. Handbook of Consumer Behavior (pp. 50-84), Englewood Cliffs, NJ: Prentice Hall.

Carl, Patrik Nilsson. (2006). Attention to Advertising. Umeå School of Business - Sweden. [Online] Available: http://umu.diva-tal.org/smash/get/diva2:144946/FULLTEXT01

Clark, Eddi M. (1994). Attention, attitude, and affect in response to advertising. Lawrence Erlbaum Associates.

Coyle, J.R., and Thorson, E. (2001). The Effects of Progressive levels of interactivity and vividness in Web Marketing site. Journal of Advertising, 30(3), 65-77.

Dahlen, M., \& Bergendahl, J. (2001). Information and Transforming on the Web. International Journal of Advertising, 20(2), 189-205.

Darroch, Jenny. (2004). Definition of Marketing and its Relationship to a Market Orientation. Journal of Marketing Theory \& Practice, 12 (4), 29-38.

Duncan, Tom \& Sandra E. Moriarty. (1998). A Communication-Based Marketing Model of Managing Relationships. Journal of Marketing, 62 (2). http://dx.doi.org/10.2307/1252157

Farbey, A.D. (2007). How to produce successful advertising. New York: Prentice-Hall Pub. Co.

Fox, Robert. (1999). News Tracks. Communication of the ACM, 42(5), 9-10. http://dx.doi.org/10.1145/301353.301385

Hamidizadeh, Mohammad Reza et al. (2011). A model for explanation of customer satisfaction consequences in banking industry. International Business and Management, 3(1), 141-147.

Hassangholipour, T., Anoushh, M., Mousavi, S. M., and Mohseni, A. (2009). Advertisement management. Negah danesh publications, 1 .

Heath, Robert. (2007). Emotional Persuasion in Advertising: A Hierarchy-of-Processing Model. University of Bath School of Management Working Paper Series.

Kotler, Ph. (2003). Analyzing, planning, implementing, and controlling. New York, Acrobat Publications, 1.

Lavidge, Robert \& Gary Steiner. (1996). A Model for Predictive Measurements of Advertising Effectiveness. Journal of Marketing, Oct., 59-62.

Li, Hairong \& Bukovac, Janice L. (1999). Cognitive Impact of Banner Ad Characteristics: An experimental study. Journalism and Mass Communication Quarterly, 76(2), 341-353. http://dx.doi.org/10.1177/107769909907600211

Maxol, J. (2003). Attitudes management, what every leader should know. Tehran, Fara Publications.

Mowen, J.C., \& Minor, M.S. (2009). Consumer behavior. Tehran, Aval Publications, 1.

$\mathrm{Ng}$ Ka Po. (2006). Factors Affecting Attitude toward Web Advertising. Hong Kong, Bapsit University.

Ngai, E.W.T. (2003). Internet Marketing Research (1987-2000): A Literature Review and classification. European Journal of Marketing, 37(1/2), 24-49. [Online] Available: www.emeraldinsight.com

Nilsson, Carl Patrik (2006). Attention to Advertising. Umea School of Business, Umea University SE-90187 Umea, Sweden.

Numberger S., \& Schwaiger M. (2003). Cross Media, Print and Internet Advertising: Impact of Medium On Recall, Brand Attitude And Purchase Intention. Seminar Proceedings: Quantitative Marketing Methods.

Patsioura, Fotini, Maro Vlachopoulou \& Vicky Manthou. (2009). A New Advertising Effectiveness Model for Corporate Advertising Web Sites: A Relationship Marketing Approach. Benchmarking Journal, 16, 372-386. [Online] Available: www.emeraldinsight.com

Rettie R., Robinson H., \& Jenner B. (2003). Does Internet Advertising Alienate Users? Kingston University. 
Rodgers, Shelly. (2003). The Effects of Sponsor Relevance on Consumer Reactions to Internet Sponsorship. Journal of Advertising, 32(4), 68-76.

Sarmad, Z., Bazargan, A., and Hejazi, E. (2001). Research Methods in Behavioral Sciences. Tehran, Agah Publications.

Schramm, W. (1995). How Communication Works. IL: University of Illinois Press, 3-26.

Thomson, Margrethe Dal. (1996). Advertising on the Internet. Dissertation submitted to the University of Westminster for the Masters Degree in Marketing.

Venous, D., Ebrahimi, A., and Roosta, A. (2001). Marketing research: applied approach. Tehran, Samt publications.

Wang, Ying \& Shaojing, Sun. (2010). Examine the Role of Beliefs and Attitude in Online advertising: A Comparison between the USA and Romania. Journal of International Marketing Review, 27(1), 87-107. http://dx.doi.org/10.1108/02651331011020410

Wolin, Lori D., \& Pradeep Korgaonkar. (2003). Web Advertising: Gender Differences in Beliefs, Attitude and Behavior. Journal of Internet Research, 13(5), 375-385. http://dx.doi.org/10.1108/10662240310501658

Zhang H. X., Li Jia \& Hean Tat Keh. (2006). Examining the Antecedents and Consequences of Advertising Value from the Perspective of Chinese Adolescents. Pecking University, Beijing 100871, China.

Zhang P., \& Wang C. (2005). An Empirical Study on Consumers Perceived Value and Attitude Advertising Global Information Technology and Management. (GITM) World Conference. (5-7).

Table 1. Combination of questions in the questionnaire

\begin{tabular}{|l|l|}
\hline \#of Questions & Variables \\
\hline 37 & Content Motives (7 motives) \\
\hline 34 & Communicate Motives (7 motives) \\
\hline 5 & Cognitive Response \\
\hline 5 & Affective Response \\
\hline 5 & Attitude \\
\hline 3 & Behavioral Response \\
\hline
\end{tabular}


Table 2. Statistical results from analysis of research variables

\begin{tabular}{|c|c|c|c|c|c|c|c|c|}
\hline $\begin{array}{c}\text { \# of } \\
\text { variables } \\
\end{array}$ & $\begin{array}{l}\text { Research } \\
\text { Variables }\end{array}$ & $\begin{array}{l}\mathrm{T} \text { test } \\
\text { value }\end{array}$ & $\begin{array}{c}\text { Critical } \\
\text { value }\end{array}$ & $\begin{array}{c}\text { Sig. } \\
\text { (2-tailed) }\end{array}$ & Mean & $\mathrm{H}_{0}$ & $\mathrm{H}_{1}$ & $\begin{array}{l}\text { Quality of } \\
\text { variables } \\
\end{array}$ \\
\hline 1 & Informativeness & -2.499 & $1.96 \pm$ & 0.013 & 2.9019 & $\square$ & a & $\begin{array}{l}\text { under } \\
\text { mean }\end{array}$ \\
\hline 2 & Entertaining & 3.203 & $1.96 \pm$ & 0.001 & 3.1639 & $\square$ & घ & $\begin{array}{l}\text { Upper } \\
\text { mean }\end{array}$ \\
\hline 3 & Irritation & -2.785 & $1.96 \pm$ & 0.006 & 2.8867 & $\square$ & घ & $\begin{array}{l}\text { under } \\
\text { mean }\end{array}$ \\
\hline 4 & Credibility & -6.352 & $1.96 \pm$ & 0.000 & 2.7013 & $\square$ & - & $\begin{array}{l}\text { under } \\
\text { mean }\end{array}$ \\
\hline 5 & Demographic & -8.087 & $1.96 \pm$ & 0.000 & 2.6251 & $\square$ & घ & $\begin{array}{l}\text { under } \\
\text { mean }\end{array}$ \\
\hline 6 & Searching & 5.140 & $1.96 \pm$ & 0.000 & 3.2395 & $\square$ & घ & $\begin{array}{l}\text { Upper } \\
\text { mean }\end{array}$ \\
\hline 7 & $\begin{array}{c}\text { Updating/ } \\
\text { Customized }\end{array}$ & -3.707 & $1.96 \pm$ & 0.000 & 2.8347 & $\square$ & 曰 & $\begin{array}{l}\text { under } \\
\text { mean }\end{array}$ \\
\hline 8 & Interactivity & -8.069 & $1.96 \pm$ & 0.000 & 2.6380 & $\square$ & 曰 & $\begin{array}{l}\text { under } \\
\text { mean }\end{array}$ \\
\hline 9 & Accessibility & 4.140 & $1.96 \pm$ & 0.000 & 3.1856 & $\square$ & 曰 & $\begin{array}{l}\text { Upper } \\
\text { mean }\end{array}$ \\
\hline 10 & Global & 1.366 & $1.96 \pm$ & 0.173 & 3.0828 & - & $\square$ & Mean \\
\hline 11 & $\begin{array}{l}\text { Purchase } \\
\text { facilitation }\end{array}$ & 0.940 & $1.96 \pm$ & 0.348 & 3.0487 & 曰 & $\square$ & Mean \\
\hline 12 & Personalize & -11.47 & $1.96 \pm$ & 0.000 & 2.3867 & $\square$ & 曰 & $\begin{array}{l}\text { under } \\
\text { mean }\end{array}$ \\
\hline 13 & Economizing & 7.531 & $1.96 \pm$ & 0.000 & 3.3219 & $\square$ & - & $\begin{array}{l}\text { Upper } \\
\text { mean }\end{array}$ \\
\hline 14 & $\begin{array}{c}\text { Measurement and } \\
\text { feedback }\end{array}$ & -3.210 & $1.96 \pm$ & 0.001 & 2.8578 & $\square$ & - & $\begin{array}{l}\text { under } \\
\text { mean }\end{array}$ \\
\hline 15 & $\begin{array}{l}\text { Cognitive } \\
\text { response }\end{array}$ & 5.393 & $1.96 \pm$ & 0.000 & 3.2359 & $\square$ & - & $\begin{array}{l}\text { Upper } \\
\text { mean }\end{array}$ \\
\hline 16 & $\begin{array}{l}\text { Affective } \\
\text { response }\end{array}$ & -3.400 & $1.96 \pm$ & 0.001 & 2.8428 & $\square$ & घ & $\begin{array}{l}\text { under } \\
\text { mean }\end{array}$ \\
\hline 17 & Attitude & -4.103 & $1.96 \pm$ & 0.000 & 2.8186 & $\square$ & - & $\begin{array}{l}\text { under } \\
\text { mean }\end{array}$ \\
\hline 18 & $\begin{array}{l}\text { Behavioral } \\
\text { response }\end{array}$ & -3.392 & $1.96 \pm$ & 0.001 & 2.8497 & $\square$ & घ & $\begin{array}{l}\text { under } \\
\text { mean }\end{array}$ \\
\hline
\end{tabular}




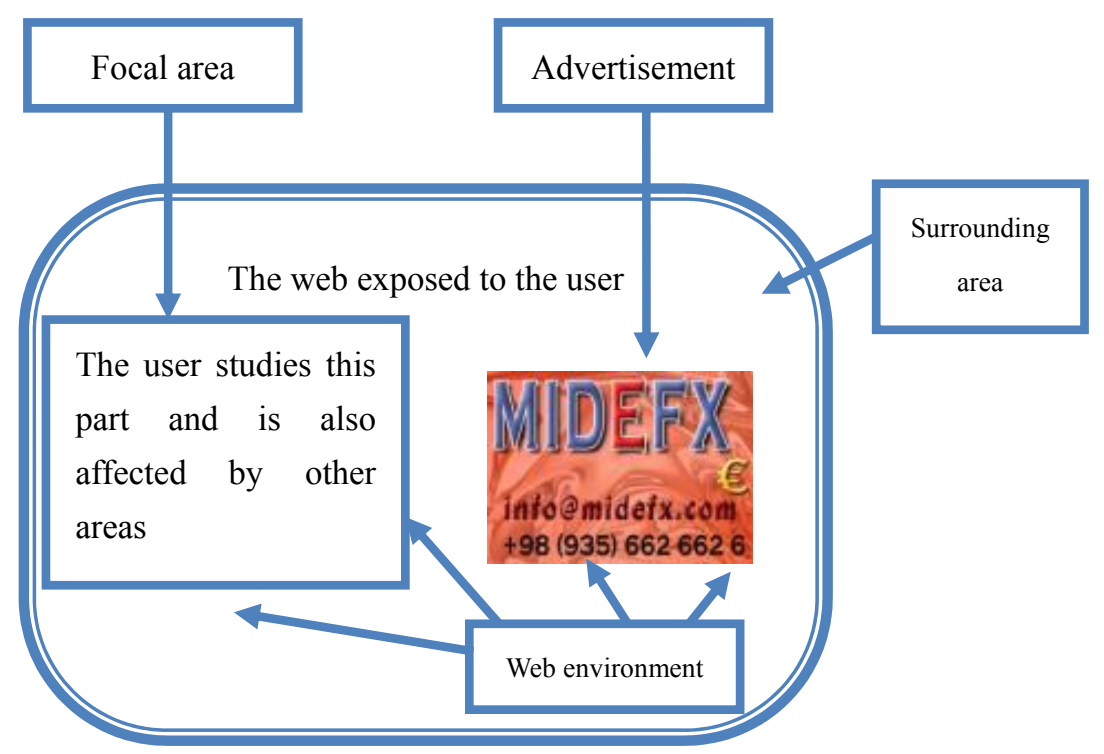

Figure 1. The environment displayed in a web advertisings

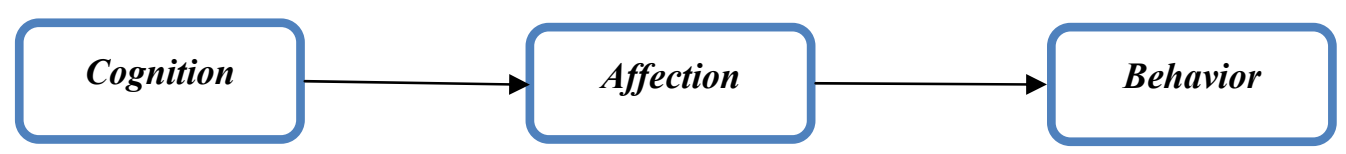

Figure 2. CAB Hierarchy

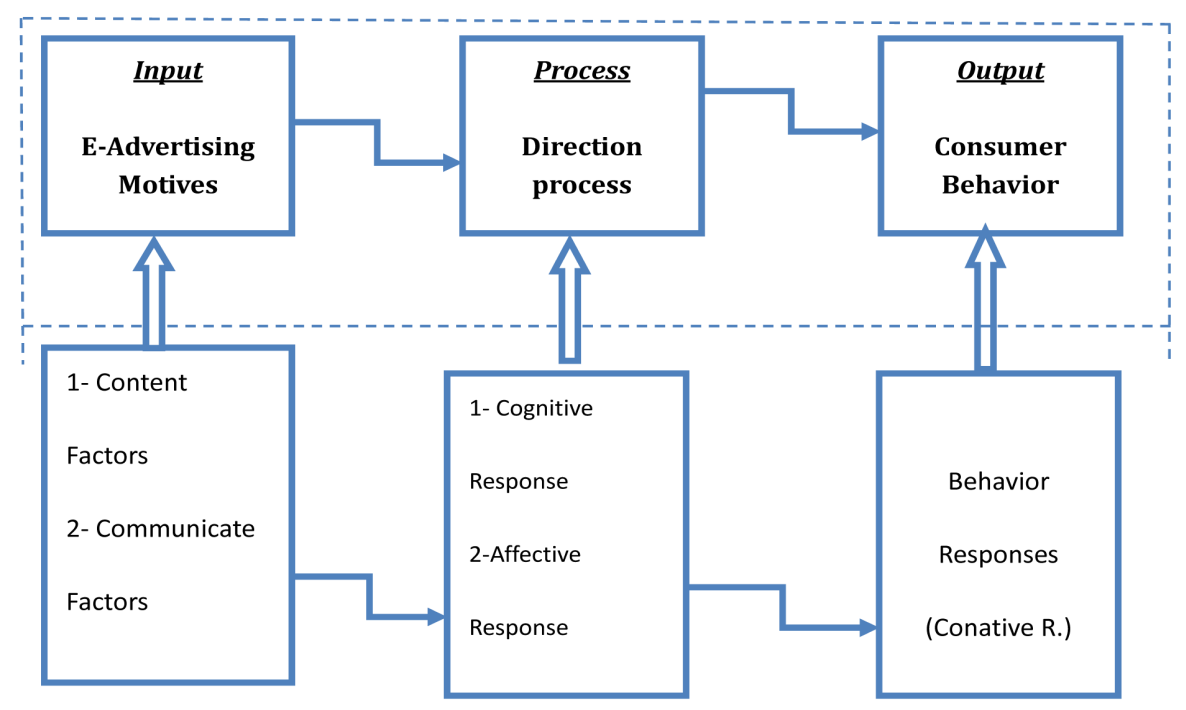

Figure 3. E-advertising research models 


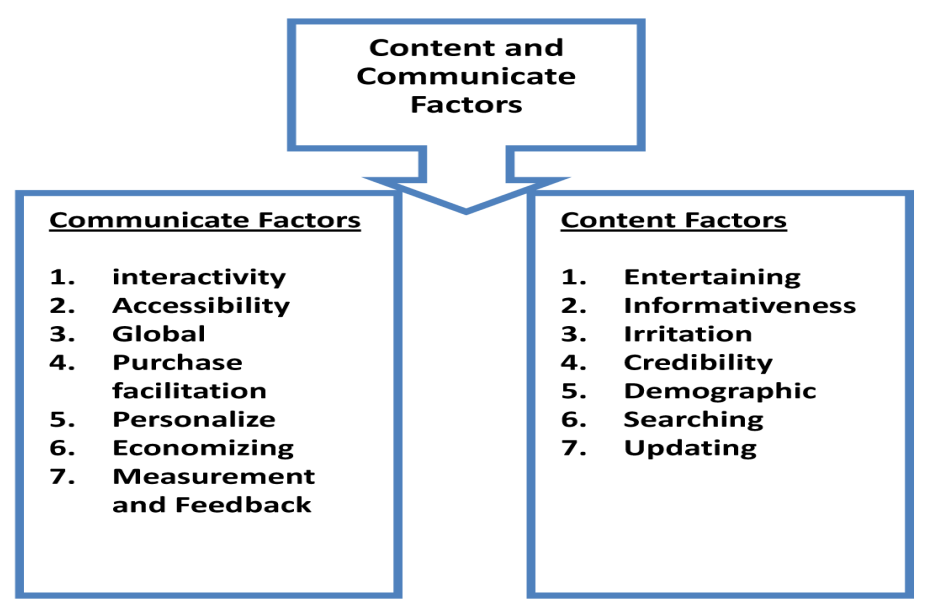

Figure 4. Indices for measuring content factors and communicate factors

1. Process of forming the

Cognitive

Response

2. Process of forming the affective response

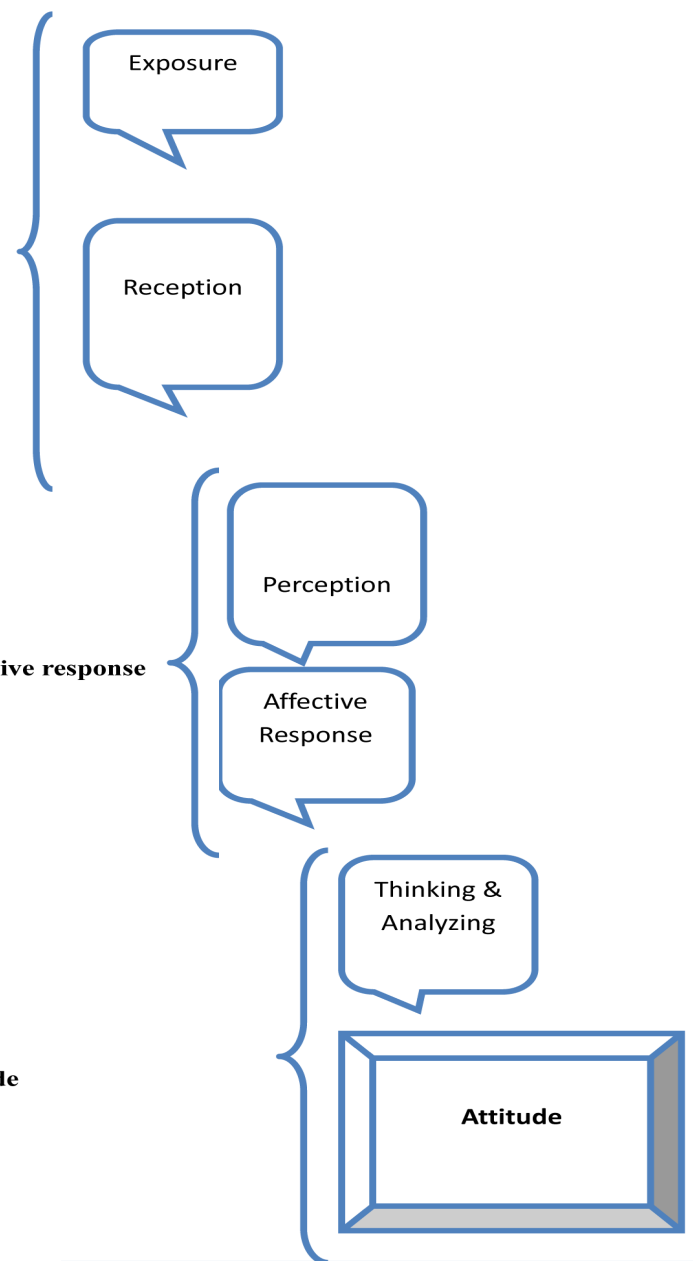

Figure 5. Explaining the leading process 


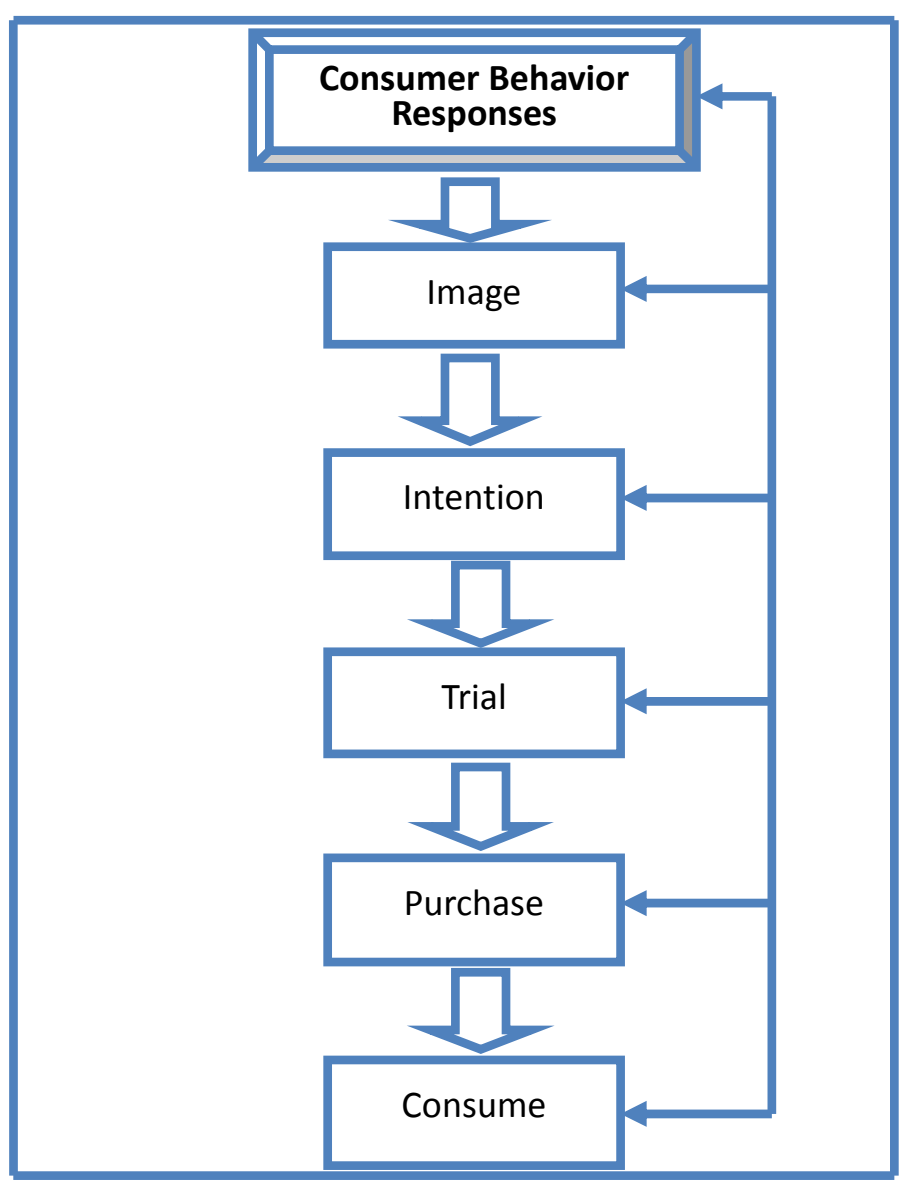

Figure 6. Explaining the factors of consumer behavior response 


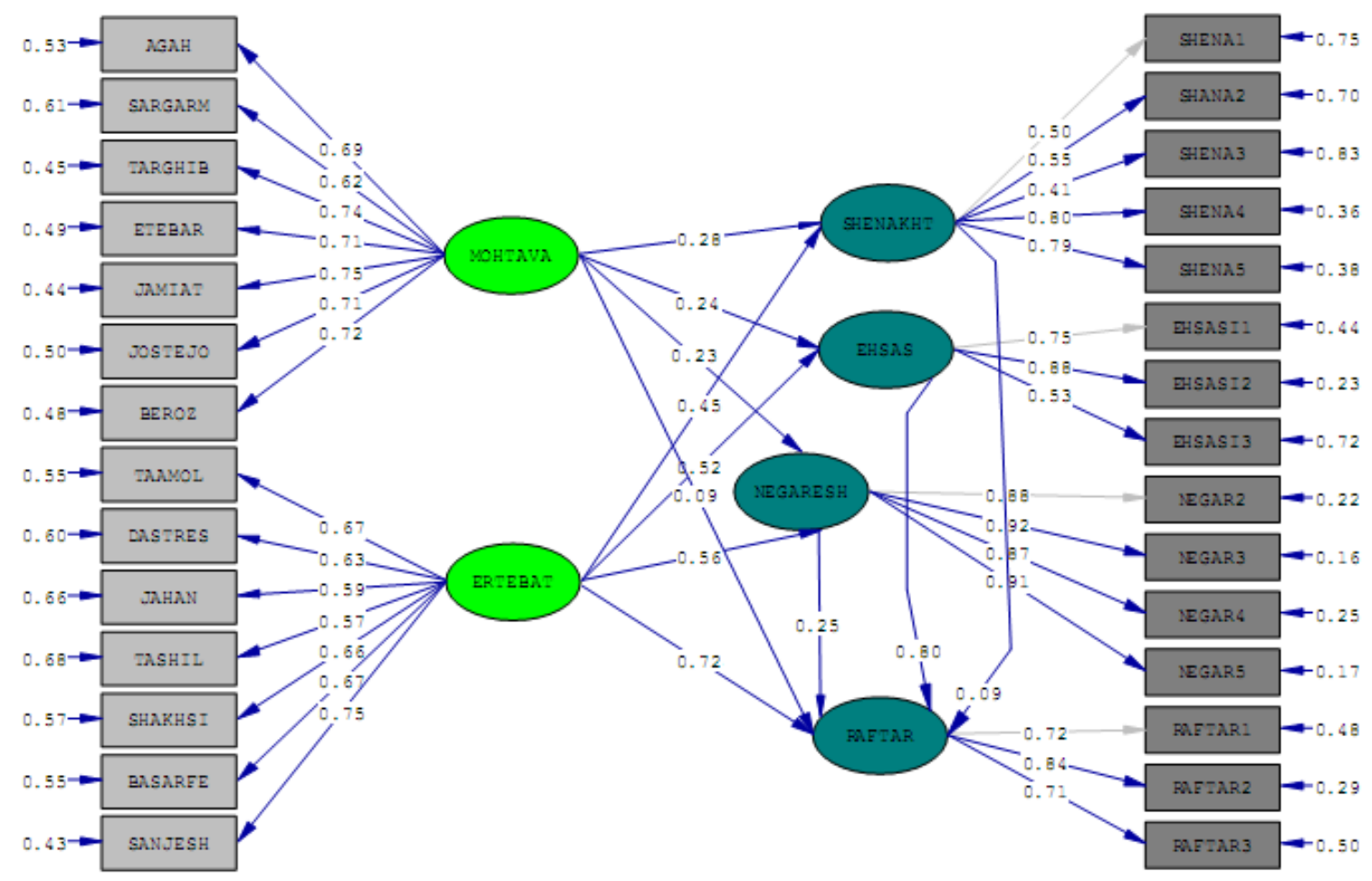

Chi-Square $=980.02, d f=365, \mathrm{P}-\mathrm{value}=0.00000, \mathrm{RMSEA}=0.044$

Figure 7. A structure equation model in terms of a standard estimate

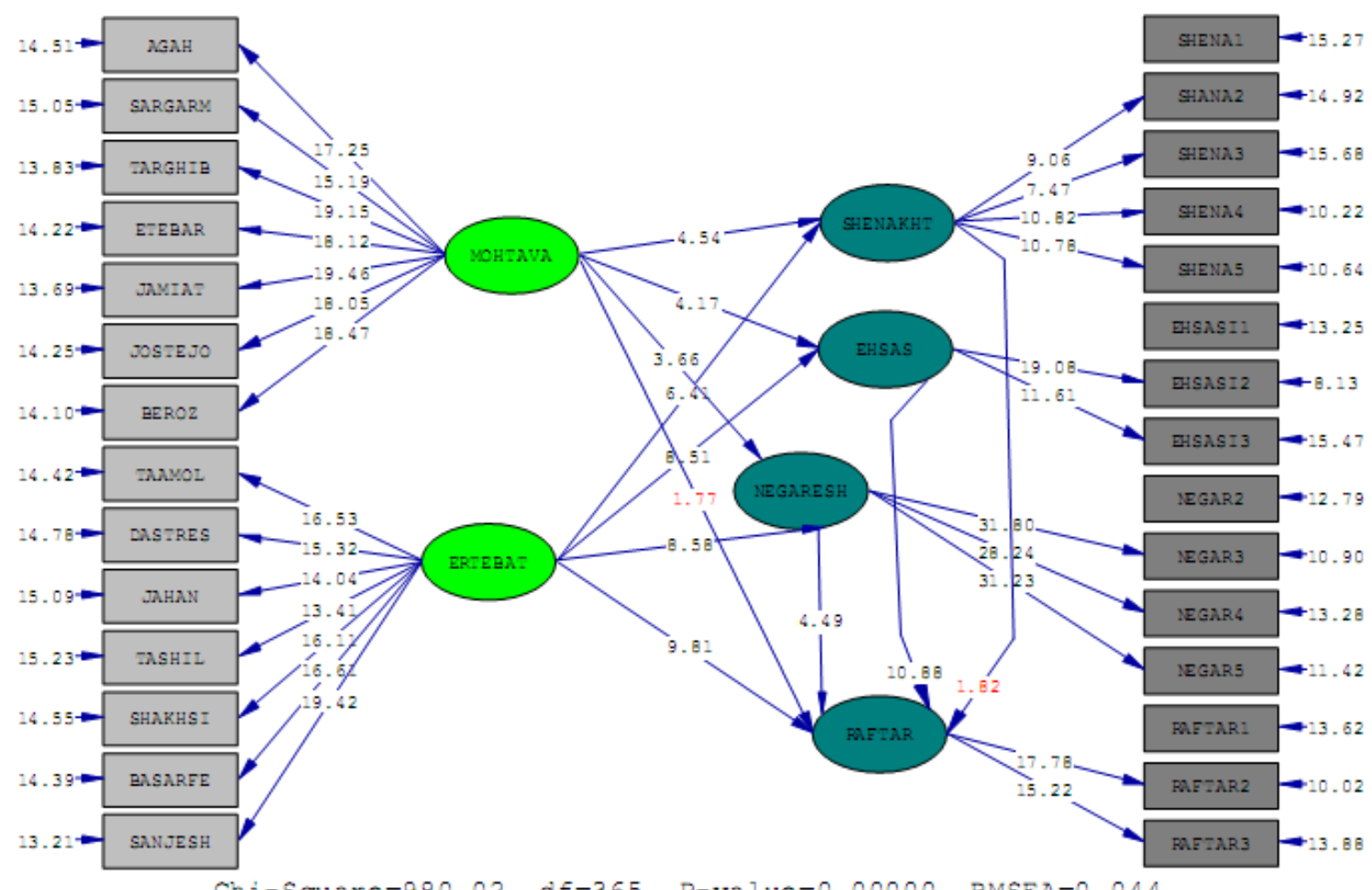

Chi-Square $=980.02, d f=365, P-v a l u e=0.00000$, RMSEA $=0.044$

Figure 8. A structure equation model in terms of significant coefficients 
Appendix 1. Codebook of Figure 7 and Figure 8

\begin{tabular}{|c|c|c|}
\hline Row & Codebook & Variables \\
\hline 1 & AGAH & Informativeness \\
\hline 2 & SARGARM & Entertaining \\
\hline 3 & TARGHIB & Irritation \\
\hline 4 & ETEBAR & Credibility \\
\hline 5 & JAMIAT & Demographic \\
\hline 6 & JOSTEJO & Searching \\
\hline 7 & BEROZ & Updating/Customized \\
\hline 8 & TAAMOL & Interactivity \\
\hline 9 & DASTRES & Accessibility \\
\hline 10 & JAHAN & Global \\
\hline 11 & TASHIL & Purchase facilitation \\
\hline 12 & SHAKHSI & Personalize \\
\hline 13 & BASARFE & Economizing \\
\hline 14 & SANJESH & Measurement and feedback \\
\hline 15 & MOHTAVA & Content motives \\
\hline 16 & ERTEBAT & Communicate motives \\
\hline 17 & SHENAKHT & Cognitive response \\
\hline 18 & EHSAS & Affective response \\
\hline 19 & NEGARESH & Attitude \\
\hline 20 & RAFTAR & Behavioral response \\
\hline 21 & SHENA1 & Cognitive response 1 \\
\hline 22 & SHENA2 & Cognitive response 2 \\
\hline 23 & SHENA3 & Cognitive response 3 \\
\hline 24 & SHENA4 & Cognitive response 4 \\
\hline 25 & SHENA5 & Cognitive response 5 \\
\hline 26 & EHSAS1 & Affective response 1 \\
\hline 27 & EHSAS2 & Affective response 2 \\
\hline 28 & EHSAS3 & Affective response 3 \\
\hline 29 & NEGAR1 & Attitude 1 \\
\hline 30 & NEGAR2 & Attitude 2 \\
\hline 31 & NEGAR3 & Attitude 3 \\
\hline 32 & NEGAR4 & Attitude 4 \\
\hline 33 & NEGAR5 & Attitude 5 \\
\hline 34 & RAFTAR1 & Behavioral response 1 \\
\hline 35 & RAFTAR2 & Behavioral response 2 \\
\hline 36 & RAFTAR3 & Behavioral response 3 \\
\hline
\end{tabular}


Appendix 2. Questionnaire

\begin{tabular}{|c|c|c|c|c|c|c|}
\hline Row & Question & $\begin{array}{l}\text { Strongly } \\
\text { agree } \\
\text { (5) }\end{array}$ & $\begin{array}{l}\text { Agree } \\
\text { (4) }\end{array}$ & $\begin{array}{c}\text { No } \\
\text { comment } \\
(3)\end{array}$ & $\begin{array}{l}\text { Disagree } \\
\text { (2) }\end{array}$ & $\begin{array}{l}\text { Strongly } \\
\text { disagree } \\
\text { (1) }\end{array}$ \\
\hline 1 & $\begin{array}{l}\text { Internet advertisements tell the truth about } \\
\text { products. }\end{array}$ & & & & & \\
\hline 2 & $\begin{array}{l}\text { Internet advertisements provide necessary and } \\
\text { sufficient information about products. }\end{array}$ & & & & & \\
\hline 3 & $\begin{array}{l}\text { Internet advertisements explain the usage and } \\
\text { applications of products correctly. }\end{array}$ & & & & & \\
\hline 4 & $\begin{array}{l}\text { Internet advertisements provide different } \\
\text { characteristics of products. }\end{array}$ & & & & & \\
\hline 5 & Observing internet advertisements is enjoyable. & & & & & \\
\hline 6 & $\begin{array}{l}\text { Internet advertisements are suitable means of } \\
\text { spending time. }\end{array}$ & & & & & \\
\hline 7 & $\begin{array}{l}\text { Using music, animation, etc in internet } \\
\text { advertisements is entertaining. }\end{array}$ & & & & & \\
\hline 8 & $\begin{array}{l}\text { When I observe internet advertisements, I get } \\
\text { entertained. }\end{array}$ & & & & & \\
\hline 9 & $\begin{array}{l}\text { After observing internet advertisements, I will } \\
\text { get interested in the advertised product. }\end{array}$ & & & & & \\
\hline 10 & $\begin{array}{l}\text { After observing internet advertisements, I will } \\
\text { prefer the advertised product. }\end{array}$ & & & & & \\
\hline 11 & $\begin{array}{l}\text { After observing internet advertisements, I will } \\
\text { have a good impression to the advertised } \\
\text { product. }\end{array}$ & & & & & \\
\hline 12 & $\begin{array}{l}\text { After observing internet advertisements, I } \\
\text { would like to try the advertised product. }\end{array}$ & & & & & \\
\hline 13 & $\begin{array}{l}\text { After observing internet advertisements, I } \\
\text { would like to buy the advertised product. }\end{array}$ & & & & & \\
\hline 14 & $\begin{array}{l}\text { After observing internet advertisements, I } \\
\text { would like to consume the advertised product. }\end{array}$ & & & & & \\
\hline 15 & I believe in internet advertisements. & & & & & \\
\hline 16 & I trust internet advertisements. & & & & & \\
\hline 17 & $\begin{array}{l}\text { I trust the address, telephone number, and the } \\
\text { advertised information of products in internet } \\
\text { advertisements. }\end{array}$ & & & & & \\
\hline 18 & $\begin{array}{l}\text { Internet advertisements have reliable and valid } \\
\text { information. }\end{array}$ & & & & & \\
\hline 19 & $\begin{array}{l}\text { Internet advertisements are separated for } \\
\text { different consumers' age groups and are } \\
\text { desirable. }\end{array}$ & & & & & \\
\hline 20 & $\begin{array}{l}\text { Internet advertisements are separated for } \\
\text { different consumers' classes of income and are } \\
\text { desirable. }\end{array}$ & & & & & \\
\hline 21 & $\begin{array}{l}\text { Internet advertisements are applicable to } \\
\text { different segments of society. }\end{array}$ & & & & & \\
\hline 22 & $\begin{array}{l}\text { Internet advertisements are separated for } \\
\text { different segments of society with regard to } \\
\text { education levels and are desirable. }\end{array}$ & & & & & \\
\hline 23 & $\begin{array}{l}\text { Internet advertisements are generally applicable } \\
\text { to different segments of consumers. }\end{array}$ & & & & & \\
\hline 24 & Internet advertisements let the users search. & & & & & \\
\hline 25 & In internet advertisements, there is a possibility & & & & & \\
\hline
\end{tabular}




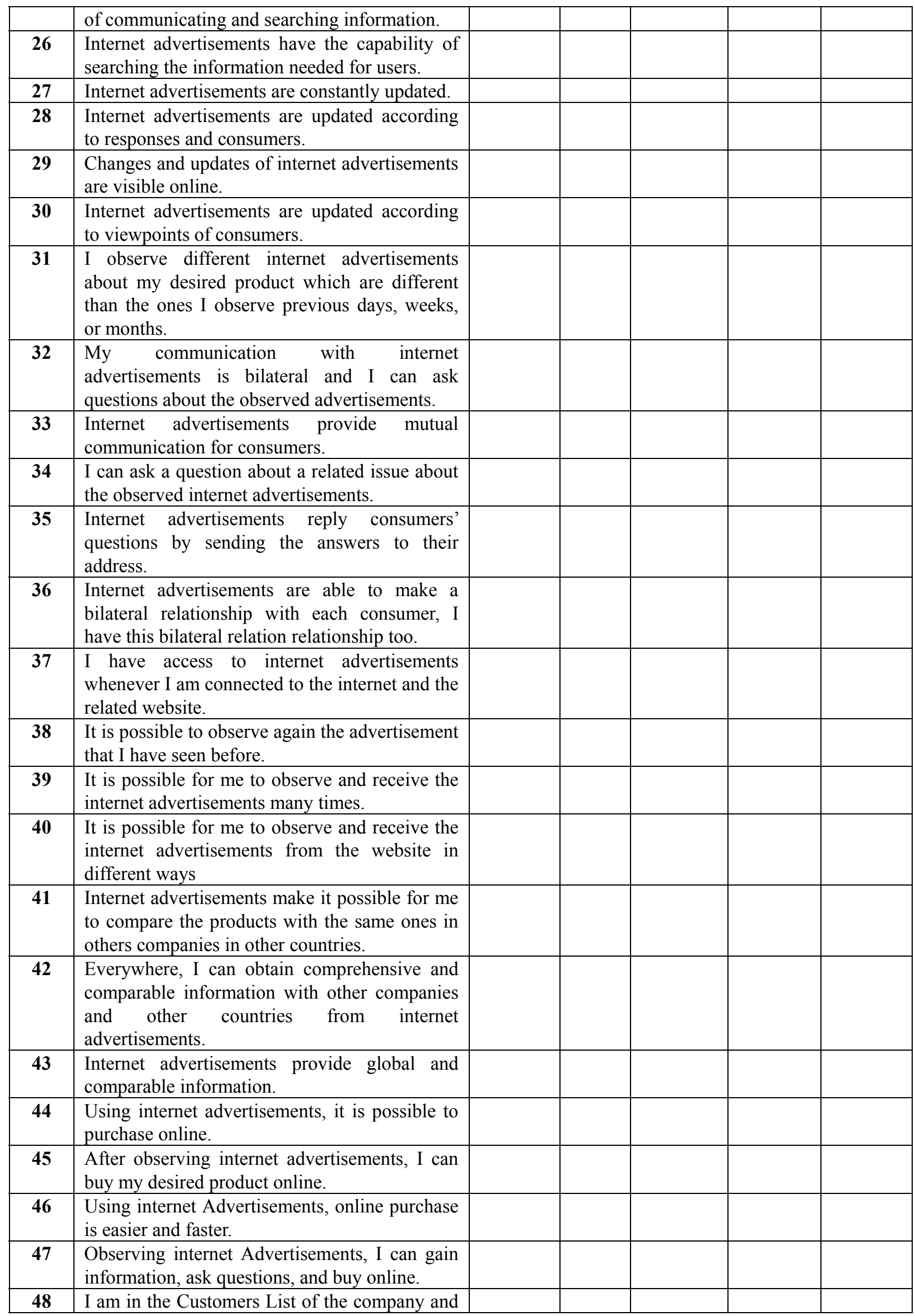




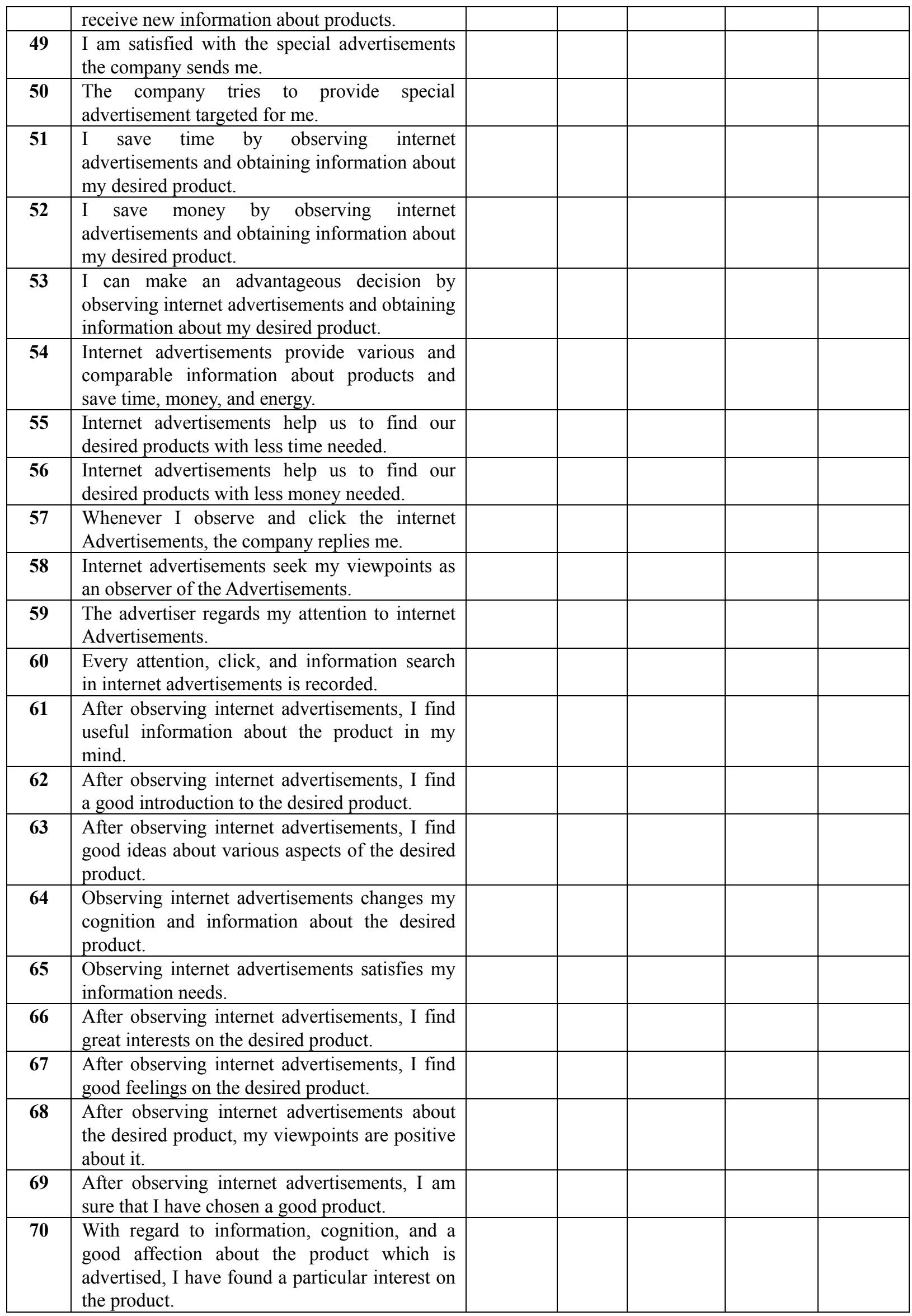




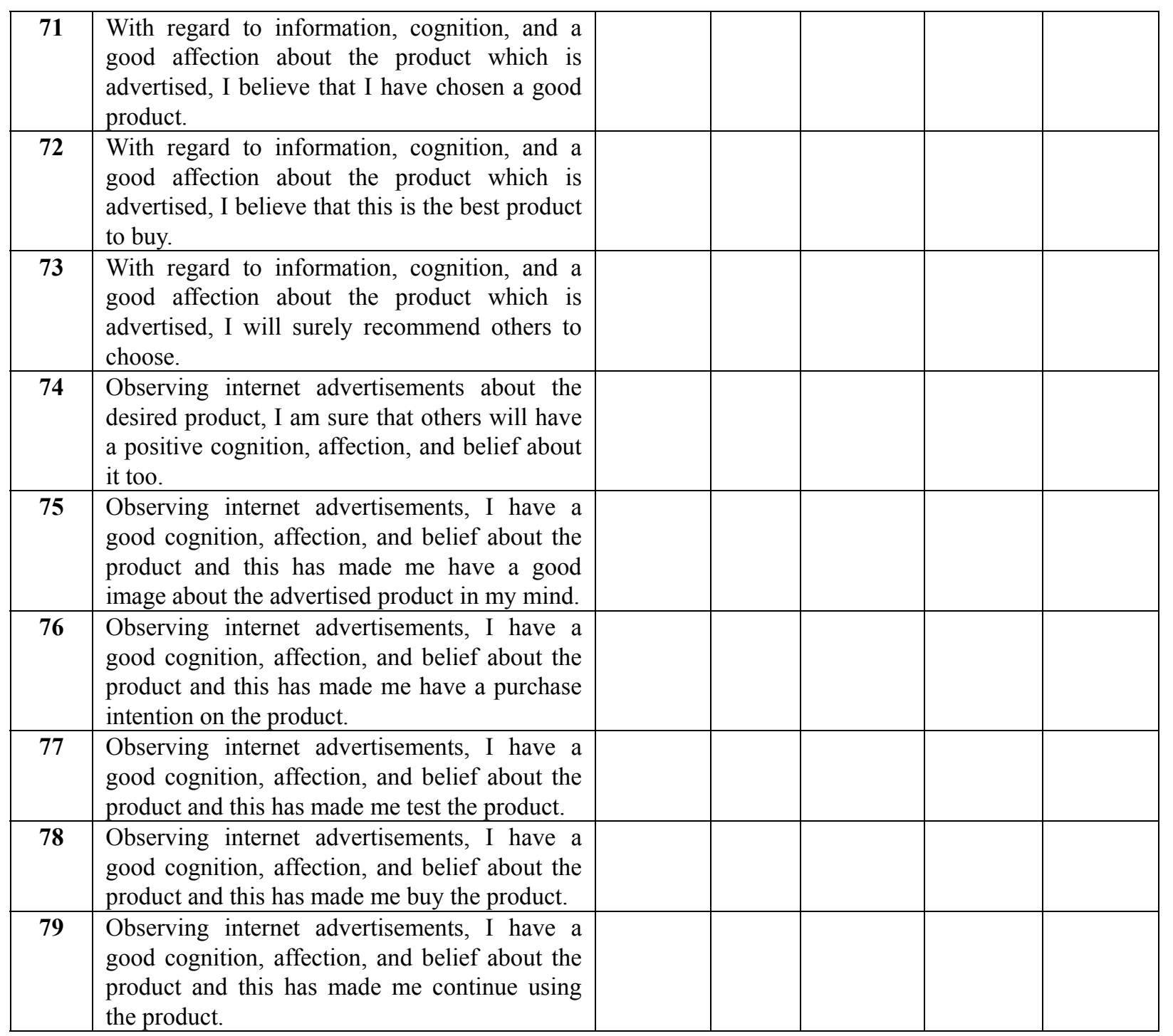

